\title{
The Role of Host Country Factors and Institutional Framework for FDI Spillovers in Ethiopia: Evidence from Manufacturing Industry
}

\author{
Eyayu Tesfaye \\ Lecturer, Department of Economics, Addis Ababa University, Addis Ababa, Ethiopia
}

\begin{abstract}
This study is aimed at assessing the role of host country factors and institutions in mediating the intra-industry productivity spillovers in the manufacturing industry. In this study, we use firm-level survey data on large and medium scale manufacturing industries collected by the Central Statistics Authority (CSA) of Ethiopia. Panel data econometrics with fixed effects estimation technique is used as a method of analysis. After addressing all the estimation issues, we estimate the baseline model containing only the interaction terms as an explanatory variable and the extended model incorporating observable and unobservable control variables. The observable control variables, industry fixed effects and firm fixed effects are included in the model after checking their respective significance. We incorporate these variables in our estimation to be more confident in isolating the spillovers effect of FDI on productivity of domestic firms. The estimation result revealed that the intra-industry spillovers effect of FDI on productivity of domestic firms is positive except through the labor mobility channel which will not be reversed even in one year. In contrast, the estimation result suggests that the degree of openness, human capital stock and financial sector efficiency positively and significantly mediates the productivity effect from FDI. Concerning the control variables included in the model, capital intensity and age positively and significantly affects domestic firms' productivity.
\end{abstract}

Keywords: FDI Spillovers, Panel Data Econometrics, Fixed Effects Estimation

DOI: $10.7176 / \mathrm{JESD} / 10-17-06$

Publication date:September $30^{\text {th }} 2019$

\section{Introduction}

1.1. Background of the study

Ethiopian economy is one of the fastest growing economies in Sub-Saharan Africa. The country has been experiencing economic growth of 10.6 percent per year for the last decade which is over and above the regional average of 5.2 percent (WB, 2012). Accordingly, agriculture accounts 42.7 percent of the GDP, industry accounts for 12.3 percent of the GDP and service sector accounts for 45 percent of the GDP of the country (OECD, 2014). The share of the industrial sector to GDP of the country is less than the Sub-Saharan Africa average of 28 percent (Melaku, 2013). Moreover, the contribution of large and medium scale manufacturing industries to GDP of the country remains very small accounting for 3 percent.

In relation to the rapid economic growth and investment policy reforms; the number and type of FDI inflow to the country has been increasing (Demeke et al., 2012). The government and policy makers gave considerable attention to attract more foreign direct investment as it affects the economy directly and indirectly. Most of the empirical studies on the direct contribution of FDI to economic growth and its major determinants shows consistent outcome (Henok, 2014; Demeke et al., 2012). FDI also affects the domestic economy indirectly through various channels one of which is productivity improvement of domestic firms resulting from technology and knowledge spillovers (Costa da Massingue, 2012; Farole and Winkler, 2012).

Depending on the direction of technology and knowledge diffusion; FDI spillovers can be either intra-industry or inter-industry. The presence of multinationals within a given industry affects the productivity of the local firms either positively or negatively through competition or labor turnover channels which, in turn, depend on the other national characteristics and institutional framework. Whether the intra-industry spillovers effect is positive or negative and how the interaction of foreign presence with macro factors affects the magnitude of FDI spillovers requires further empirical investigation as the research outcomes shows inconsistent results.

\subsection{Statement of the problem}

Despite the prediction of economic literatures that knowledge and technology spillovers from FDI enhances the productivity of domestic firms; empirical investigations shows mixed results (Havranek and Irsova, 2011; Jude, 2013; Lipsey and Sjoholm, 2005). Some studies found that the existence of foreign firms with in the same industry enhances the productivity of domestic firms (Merlevede and Schoors, 2007; Nicolini and Resmini, 2010). Others revealed that the presence of foreign firms adversely affects the productivity of local firms operating within same industry (Farole and Winkler, 2012; Javorcik, 2004). Some other studies found that the intra-industry productivity effect of FDI is not significant (Girma, 2005). All of these studies in common overlook the role of mediating 
factors in determining the extent of FDI spillovers in their respective analysis.

According to Costa da Massingue (2012) and Farole et al (2014) the spillovers effect of FDI do not accrue automatically with the presence of multinationals. The characteristics of foreign firms, which shapes spillover potential; domestic firms capacity which shapes absorptive capacity to internalize the spillovers; and host country factors and institutions determine the magnitude of FDI spillovers.

The interaction of intra-industry FDI spillovers with the host country factors and institutional framework affects productivity of domestic firms (Jude, 2013). According to Boly et al. (2013) the net impact of FDI on domestic firms largely depends on the host country factors and institutions where the other mediating factors are situated. In relation to this, national income, government's spending on research and development, trade openness, labor freedom, financial freedom and property right matters most for FDI spillovers considering heterogeneity of domestic firms (Farole et al., 2014). Empirical studies on the role of host country factors and institutions as a mediating factor in determining the extent of FDI spillovers also shows mixed results (Farole and Winkler,2012).

Some empirical studies examined the horizontal and vertical spillover effect of FDI at industry and firm level in Ethiopia. Abeba (2014) uses panel dataset and extensive econometric analysis to assess the backward, forward and horizontal spillovers effect of FDI in the manufacturing firms in Ethiopia. She found that FDI in the manufacturing industry has a negative forward spillovers effect and a positive backward spillovers effect on the productivity of domestic manufacturing industries. However, the horizontal spillovers effect is indeterminate. Similarly, Ermias (2013), by using firm level cross sectional data, analyze the spillovers effect of FDI inflow to the manufacturing sector on the productivity of domestic manufacturing firms in Ethiopia. He revealed that there is a positive intra-industry spillovers effect and the magnitude of the effect mainly depends on geographical proximity, size, age and labor quality of domestic firms.

As far as our knowledge is concerned, none of the previous studies include the host country factors and institutions role as a mediating factor in analyzing FDI spillovers in Ethiopia in general and with in the manufacturing sector in particular. This study, therefore, focuses on the horizontal spillover effect of FDI in the manufacturing industries in Ethiopia and the role of host country factors and institutions in shaping the magnitude of the horizontal spillovers.

\subsection{Objective of the Study}

The main objective of this study is analyzing the horizontal spillovers effect of FDI and its interaction with host country factors and institutional framework on productivity of domestic manufacturing firms.

1.3.1.Specific objectives

$>$ Assessing the effect of foreign firm presence on productivity of domestic manufacturing firms

$>$ Analyzing labor mobility effect of foreign firm presence within the industry

\section{Literature Review}

\subsection{Theoretical Literature}

\subsubsection{Determinant Factors of FDI Spillovers}

The existence and magnitude of FDI spillovers to domestic firms depends on various firm and macro level mediating factors (Crespo and Fontoura, 2007). The occurrence of FDI spillover depends on the presence of interaction, labor market conditions, availability and quality of institutions, trade orientation, ownership structure and size of firms among others (Gachino, 2012). According to (Farole et al.,2014) mediating factors which determine the extent of FDI spillovers can be classified as absorptive capacity of domestic firms, foreign firms spillovers potential, host country characteristics and institutional framework.

The host country characteristics and institutional framework, in turn, influences the FDI spillovers potential of foreign firms, absorptive capacity of domestic firms and transmission channels (Crespo and Fontoura, 2007; Farole and Winkler, 2012). The focus of this study is the role of host country factors and institutional framework on FDI spillovers in manufacturing industries in Ethiopia. Therefore, much section is devoted to the main arguments on the role of host country factors and institutional framework on FDI spillovers based on the conceptual framework of Farole et al (2014). 
Figure1: Role of Mediating Factors for FDI Spillovers: A Conceptual Framework

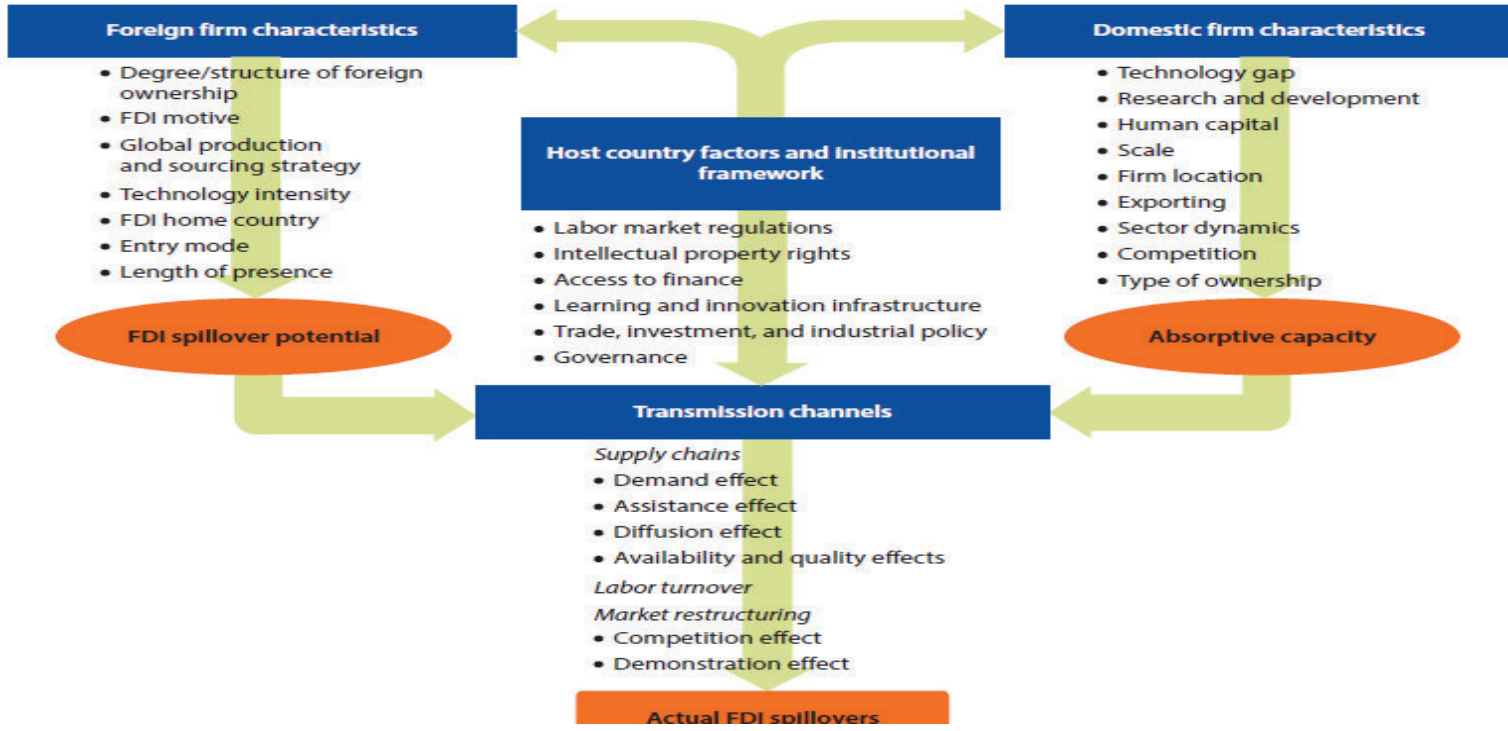

Source: Making FDI Work for Sub-Saharan Africa Farole et al (2014)

\subsubsection{Host Country Factors and Institutional Framework: Main Arguments}

As shown in the above conceptual framework, labor market regulation, trade, investment and industrial policy, access to finance, intellectual property rights, learning and innovation infrastructure determine the magnitude of actual FDI spillovers to domestic firms. The interaction of FDI spillovers variable with these macro level factors determines the spillovers effect of FDI on the productivity of domestic firms.

Labor market regulation determines the type and the amount of FDI, willingness to invest in job training and workers skill which, in turn, determines domestic firms' absorptive capacity. It also affects the transmission channel through the nature and frequency of labor turnover. Highly rigid labor market reduces the possibility of labor turnover and highly flexible labor market may result in frequent turnover which reduces chance for acquiring spillovers (Farole and Winkler, 2012; Hale and Long, 2011).

Some argue that strong intellectual property rights increase the inflow of FDI and possibility of spillovers. Others argue that strong intellectual property rights is a barrier for domestic firms to imitate and may lead to less positive horizontal spillovers (Crespo and Fontoura, 2007; Smeets, 2011). Multinationals use protection of intellectual property rights to prevent technological spillovers; if domestic firms are competing with in the same sector. Loose protection of intellectual property rights makes multinationals to prefer distribution and marketing activity to local production which reduces the occurrence of spillovers (Javorcik, 2004).

The role of access to finance as mediating factor for FDI spillovers is also controversial. Some argue that well developed financial system favors the existence of FDI spillovers as it reduces the risk of investment to imitate technology and skill development of workers (Agarwal et al., 2011; Hermes and Lensink, 2003). Better access to finance enhances the absorptive capacity of domestic firms and their benefit from technological spillovers. Moreover, horizontal spillovers will be lower in countries with lower financial development (Alfaro et al., 2004). Others argue that when multinationals borrow from local institutions; financial constraint for local firms will be high and their absorptive capacity and spillovers potential will be low (Farole and Winkler, 2012; Havranek and Isrova, 2011).

The other important mediating factors determining FDI spillovers are learning and innovation infrastructure, trade, investment and industrial policy. Trade policy is identified as most important catalyst for FDI spillovers. Trade openness can increase the productivity spillovers from FDI; while trade barrier encourages investment in less productive import substituting industries. This is called the "Bhagwati" Hypothesis" (Lesher and Miroudot, 2008; Havranek and Irsova, 2011). Bhagwati (1978) hypothesized that a country with an export-oriented trade policy will attract a greater volume of FDI and use the resource efficiently relative to the one that adopts importsubstitution strategy. Therefore, FDI spillovers are likely to be positive in a country that adopts export promotion policy than import substitution regime.

Some other studies argue that inward-oriented trade policies make multinationals to focus on local markets and use new technologies which results in high FDI spillover through learning and demonstration effect (Crespo and Fontoura,2007; Kokko et al, 2001). Human capital is also a crucial mediating factor in enhancing the productivity of local firms. According to Rao and Tesfahunegn (2015) adopting and sustaining modern technology and improving productivity of firms requires skilled worker.

Exporting is the other channel through which domestic firms can benefit from existence of multinationals 
(Greenway et al, 2004). There is no clear evidence whether exporting improves or lowers the extent of positive FDI spillovers (Falore et al, 2014). On one hand, by adopting export process of foreign firms, domestic firms will reduce entry cost to international market and enhance their respective productive efficiency (Crespo and Fountoura, 2007). On the other hand, if the local firm is net exporter the competitive pressure from foreign firms will be low, provided that multinationals does not enter in to the export market, which lowers the extent positive FDI spillovers (Farole and Winkler, 2012).

Analogously, investment policy and promotion also plays a significant role in mediating spillovers. Investment promotion agency arranges export processing zones which can affect the extent of FDI spillovers. Some argue that arranging special economic zones will limit the spillover potential if the exporters use larger proportion of imported inputs and if the legal structure inhibits integration of multinationals with local producers (Abraham et al, 2010). Another host country factor affecting extent of FDI spillovers is industrial policy of the country. Accordingly, policies supporting micro and small enterprises and the local content

requirements rule reduces high technological gap between the domestic and foreign firms and enhances the extent of FDI spillovers (Farole and Winkler, 2012).

Finally, the host country institutional environment can shape the extent of FDI spillovers. Corruption and poor contract enforcement leads foreign firms to internalize production or to import from intermediary reduces interaction with local suppliers (Perez-Vilar and Seric, 2014). Some also argue that institutional distance matters more than the institutional quality for linkage between multinationals and local firms (Cuevero-Cazurra and Genc, 2008). The relationship between the country's per capita income and FDI spillovers is ambiguous. Spillovers through labor mobility to domestic firms is lower in low income countries as there is high wage differential between multinationals and domestic firms (Lipsey et al., 2004).

\subsection{Empirical Literatures}

\subsubsection{Firm and Industry Level Empirical Evidences}

Lenaerts and Merlevede (2012), using Romanian firm level panel dataset and input-output table, analyse the vertical and horizontal spillovers effect of the FDI by considering the degree of industrial aggregation. The study confirms that horizontal spillovers present at higher level of aggregation whereas vertical spillovers decline with the increase in aggregation. Similarly, Merlevede and Schoors (2007) assess the spillovers effect of FDI on sample of Romanian firms and found positive horizontal effect on domestic firms through labour turnover from multinationals. However, its effect on local suppliers is negative. Nicolini and Resimini (2010) conducted similar study by incorporating firms in two more countries and analyse the role of technological gap in FDI spillovers and found that larger technological gap is a barrier for domestic firms to take advantage of positive spillovers effect.

Stancik (2009), using firm level data for Czech Republic, assess the horizontal and vertical spillovers effect of takeovers and Greenfield FDI on sales growth rate of domestic firms. He found that there is positive horizontal spillovers effect from foreign takeovers and negative horizontal spillovers effect from Greenfield FDI. The study also revealed that sales growth effect of FDI is negative in the upstream sectors. According to Amendolagine et al (2013) Greenfield investment with natural resource and market seeking motive of investors results in weak linkage and limits the FDI spillovers to domestic firms in SSA.

Zhou (2014) conducted a study on analysing the effect of FDI on the technical efficiency of domestic manufacturing firms in five African countries using stochastic frontier analysis for the period 1991 to 2003 . He reiterated that FDI presence improves the technical efficiency of large export-oriented manufacturing firms and lowers the technical efficiency of older domestic firms as compared to the new once.

Industry level empirical analysis is conducted by Abeba (2014) on the spillovers effect of FDI on the domestic manufacturing industries in Ethiopia by using panel dataset for the year 2004-2010. She found that foreign firm presence in the manufacturing sector do have positive backward spillovers and negative forward spillovers effect on the productivity of local manufacturing firms. Ermias (2013), using cross sectional data on Ethiopia for the period 2009, conducted a similar study and revealed that foreign firm presence in the manufacturing sector results in positive intra-industry spillovers effect but the magnitude depends on geographical proximity, size and age of firms among others.

Ofosu and Waldkirch (2008) assess the effect of foreign firm presence on productivity and wage paid by manufacturing industries in Ghana using firm level panel data considering differences in degree of ownership. They found that the presence of foreign firms adversely affects the productivity of domestically owned firms but positively affects most of foreign owned multinationals in the domestic economy. Moreover, there is no evidence on the effect of foreign firm presence on wage paid by domestic manufacturing firms. Gorg and Strobl (2005) also use the panel data set to analyse the productivity effect of FDI on domestic firms through labour mobility as channel of transmission in Ghana. The study revealed that mobility of experienced workers to domestic firms enhances productivity.

The net horizontal spillovers effect of FDI depends on the magnitude of the competition and labour mobility effect. The increase in productivity arising from labor turnover may be offset by the adverse competition effect. 
(Jude, 2013) assess horizontal spillovers effect of FDI on the Romanian firms and found that the effect of technological spillovers occurred through labor mobility positively affects productivity of domestic firms.

Frederick and Staritz (2012) empirically assess the spillovers effect of FDI in three leading apparel exporting countries in SSA. The study reiterated that despite FDI boom to the sector, there is no spillover effect on the local firms.

The interaction of mediating factors with FDI spillovers variable determines the productivity effect of FDI on domestic firms. (Jude, 2013) using data for Romanian firms, conducted a study on the role of mediating factors on FDI spillovers. The study revealed that the interaction of spending on research and development and larger technological gap with the horizontal spillovers variables positively affects total factor productivity of domestic firms. Similarly, the backward spillovers variable and its interaction with the technological gap also positively affect the total factor productivity of domestic firms.

Boly et al (2013) conducted a firm level analysis on the role of institutional environment as a mediating factor for sample of firms in 19 Sub-Saharan Africa countries. They reiterated that countries with weak institutional environment experience positive net effect from FDI spillovers.

Kokko et al (2001) assess the impact of the interaction FDI spillovers variable with trade policy on the productivity of Uruguayan manufacturing sector by taking 1973 as a period of demarcation for policy change. The study reiterated that FDI spillovers effect is positive during the inward oriented trade policy regime before 1973 and negative during open trade policy regime. Kohpaiboom (2009), using panel data econometric analysis, assess the spillovers effect of FDI on the productivity of manufacturing firms in Thailand considering trade policy as mediating factor. He found that trade liberalization facilitates positive horizontal spillover effect of FDI on domestic firms. The outcome is in line with the "Bhagwati' hypothesis.

The exporting status of the firm also determines the extent of FDI spillovers. Some studies argue that domestic firms engaged in exporting gain more from FDI relative to non exporters. Jordaan(2011) assess the spillover effect of FDI on domestic firms in Mexico and reiterated that intra-sector spillover from FDI benefit more the exporting firms as compared to non- exporters.

The sector or firm level spillovers effect of FDI is also determined by the labor market regulation. According to Hale and Long (2011) presence of foreign firms due to their competition effect in China creates upward pressure on the wage paid by domestic firms for skilled labors. This results in shift of low quality skilled workers to wage constrained domestic firms which, in turn, reduces the absorptive capacity of domestic firms. The intellectual property right also determines the type of FDI and the extent of spillovers to domestic firms. Javorcik (2004b) assess the role of intellectual property rights on FDI spillovers by taking sample of firms form central and Eastern Europe. He found that the magnitude of FDI spillovers is high in high tech producers with strong property right and it is lower in sector with weaker property rights.

Analogously, access to finance and spending on learning and innovative infrastructure affects the FDI spillover from multinationals to domestic firms. A study by Agrawal et al (2011) revealed that FDI spillover are lower and even negative for manufacturing firms in China having credit constraint. Tytell and Yudaeva (2007) analyses the firm level effect of availability of learning and innovative infrastructure in Romania and found that FDI spillovers effect on productivity of manufacturing firms is low in regions with lower share of spending on education.

\section{Model Specification, Estimation Results and Discussion}

\subsection{Methodology and Data}

\subsubsection{Data Description}

In this study, we use the unbalanced panel dataset of large and medium scale manufacturing firms in the Ethiopia collected by Central Statistics Authority (CSA) of the country for the period 2004 to 2015. These surveys are confined to those establishments which engage 10 persons and above and use power-driven machines for the production which covers both the private, public and foreign owned industries in all regions of the country.

In this study, we consider industries with ISIC code from 1511 to 3610 . Firms with in this range are categorized under manufacturing as per the International Standard Industrial Classification (ISIC) Revision 4.1. The number of firms per year varies from a low of 730 in 2004 to high of 1863 in 2009 . After deleting those observations with zero sales, zero employment, zero output, and missing values; a total of 11131 observations categorized under 52 manufacturing industries are included in the period under consideration. Regarding ownership, firms are classified as foreign owned and domestically owned based on their respective share of issued capital out of the total paid up capital. Accordingly, firms having the capital share of 10 percent and above are considered as FDI based on UNCTAD and OECD classification.

The firm-level data is used in combination with host country level factors and institutional framework to assess the impact of the interaction term with FDI spillovers on productivity of manufacturing firms. Moreover, WDI, ADI and Heritage foundation databases are used for the host country factors and institutional framework data. 


\subsubsection{Methodology}

In this study, panel data econometric analysis is used to assess the spillovers effect of the foreign firm presence and its interaction with host country factors and institutions on productivity of domestic firms. The magnitude and extent of FDI spillovers from multinationals can be analyzed quantitatively by observing the changes on productivity of domestic firms due to the presence of foreign firm.

\subsection{Model Specification and Definition of Variables}

\subsubsection{Model Specification}

From the model used by Blalock and Gertler (2009) as cited in Farole and Winkler (2012) the baseline model to be estimated is given as:

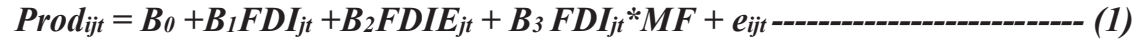

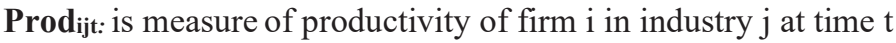

FDI $_{\mathbf{j t}}$ : is horizontal spillover variable based on value of output to capture the foreign firm presence in industry $\mathrm{j}$ at time t. This measure shows the productivity effect through channels of horizontal transfer, other than labor mobility. FDIE $_{\mathrm{jt}}$ : is horizontal spillovers variable based on employment to capture the labor mobility effect of foreign firm presence in industry $\mathrm{j}$ at time $\mathrm{t}$.

FDI $_{\mathbf{j}}$ *MF: is measure of interaction term of horizontal spillover variable with host country factors and institutional framework as a mediating factor.

$\mathbf{e}_{\mathrm{ijt}}$ : is idiosyncratic error term

In order to come up with more parsimonious model and isolate the net horizontal spillovers effect of foreign firm presence; we incorporate other control variables affecting the productivity of domestic firms to the original model. The extended model to be estimated is given as:

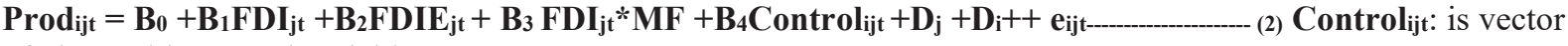
of observable control variables

$\mathbf{D}_{\mathbf{j}}$, and $\mathbf{D}_{\mathbf{i}}$ : are firm fixed effects and industry fixed effects respectively. These variables are included in the model to capture unobserved factors that affect the correlation between foreign firm presence and the productivity of domestic firms. This includes difference in access to infrastructure and attractiveness of a particular industry; management quality differences which are not explicitly included by econometricians but affects productivity of firms (Javorcik, 2004).

\subsubsection{Definition of Variables}

\subsubsection{Dependent Variable}

Productivity $\left(\operatorname{Prod}_{\mathrm{ijt}}\right)$ : in this study, the firm level productivity is proxide by labor productivity which is value added per worker (Farole and Winkler, 2012; Shiferaw and Tadele, 2015). Value added can be calculated by deducting cost incurred for materials and intermediate goods and services from total value of sales (Rao and Tesfahunegn, 2015).

\subsubsection{Explanatory Variables}

FDI $I_{j t}$ : is the output measure of intra-industry FDI presence in industry $\mathrm{j}$ at time $\mathrm{t}$ (Proxy for horizontal spillovers). The coefficient of the horizontal spillover variable shows the change in productivity of manufacturing firms caused by increase in foreign firm presence in same sector (Havranek and Irsova, 2011). This variable captures the effect of other channels of horizontal transfer after controlling for workers mobility channel and other observable and unobservable factors affecting productivity.

Based on the work of Farole and Winkler (2012), Javorcik (2004) output measure of intra-industry FDI presence at industry level at time $t$ is used as one proxy for horizontal Spillover. The horizontal spillovers is calculated by using share of foreign firms output out of the industry $j$ output at time $t$ which captures the presence of foreign firms in the industry $\mathrm{j}$ at time $\mathrm{t}$.

$$
\text { Horizontal }_{\mathrm{jt}}\left(\mathrm{FDI}_{\mathrm{jt}}\right)=\sum_{i \in j} \frac{Y_{i j t}}{Y_{j t}}
$$

$\mathbf{Y}_{\mathbf{j t}}$ is the total output of industry $\mathrm{j}$ at time $\mathrm{t}$.

$\mathbf{Y}_{\mathrm{ijt}}$ is the output of foreign firm $\mathrm{i}$ in industry $\mathrm{j}$ at time $\mathrm{t}$

We consider the firm as foreign with the foreign capital share of 10 percent or higher (Farole and Winkler, 2012; Jude, 2013). Horizontal spillovers increase with the increase in output and equity share of foreign firms within the industry (Javorcik, 2004; Jude, 2013).

Most multinationals invest on employees' knowledge and skill development training. According to Fosfuri et al (2001) knowledge transfer takes place as long as domestic firms bid and hire these employees of foreign firms who are exposed to new technologies and accumulate knowledge. Therefore, the other horizontal variable through which intra-industry knowledge spillover can be undertaken through mobility of employees. According to Merlevede and Schoors (2007) the labor mobility effect of foreign firm presence within the industry can be calculated as: 


$$
\text { Horizontal_E }\left(\mathrm{FDIE}_{\mathrm{jt} \mathrm{t}}=\sum_{i \in J} \frac{E_{i j t}}{E_{j t}}\right.
$$

$\mathbf{E}_{\mathrm{jt}}$ : is total number of employees in the manufacturing industry $\mathrm{j}$ at time $\mathrm{t}$

$\mathbf{E}_{\mathrm{ijj}}$ : is number of employees of in foreign firm $i$ in industry $j$ at time $t$

According to Jude (2013) labor mobility channel of horizontal transfer is based on the assumption that all employees of multinationals acquire and accumulate knowledge when they shift to domestic firms.

FDI $I_{\mathbf{j}} * \mathbf{M F}$ : is the interaction of measure of horizontal spillovers variable with vector of mediating factors. In this model, we include selected host country factors and institutional framework as mediating factors.

Labor (labct): represents quantitative measure of labor freedom to capture the labor market institutions in the country at time $t$. The measure includes the various aspects of legal and regulatory framework of the country's labor market. The variable ranges from lowest score 0 to the highest score 100 for labor freedom.

Finance $\left(f_{i n} n_{\mathrm{ct}}\right.$ ): represents measure of overall level of financial freedom in the country at time t. It measures banking efficiency as well as government control and interference in the financial sector which affects access to financing opportunities. The measure ranges from the lowest score 0 to 100 which shows highest financial freedom. Property rights $\left(\operatorname{Prp}_{\mathrm{ct}}\right)$ : measures the degree of legal protection of private property in the country at time $t$ which affects the firm's ability to accumulate private property. The score ranges from 0 to 100 .

Business (busct): represents measure of business freedom in the country at time t. The quantitative measure for business freedom is derived from measuring difficulty of starting, operating and closing the business based on the World Bank doing business study. The measure ranges from the lowest score 0 to 100 .

Investment (invct): represents measure of investment freedom used to capture the ability of firms to move their resources in and out of a specific activity both internally and across the country's boarder. The score ranges from 0 to 100 which show the highest investment freedom.

Openness $\left(\mathbf{O p e n}_{\mathrm{ct}}\right)$ : the share of sum of exports and imports to GDP of the country at time $\mathrm{t}$ which captures the degree of trade openness.

Human capital $\left(\right.$ hum $\left._{\mathrm{ct}}\right)$ : the tertiary and secondary school enrollment rate in the country at time $t$ which is measured by people completed secondary and tertiary education as percentage of total population obtained from ADI data base.

Gross Domestic Product (GDPct): The country's per capita GDP at time $t$ in natural logarithms which captures the country level competition and other aspects of national environment (Farole and Winkler, 2012).

Apart from the above interaction variables; the following control variables are incorporated in the model:

Firm size (Size $e_{i j t}$ ): is size of firm i in industry $j$ at time t proxide by firm's total number of employees. Firm size captures the economies of scale. The larger the firm, the higher will be the production volume and the firm becomes cost efficient and productive (Jude, 2013).

Herfindhal-Hirschmaan Index $\left(\mathbf{H H i}_{\mathbf{j t}}\right)$ : represents sector concentration to capture degree of competition in the domestic manufacturing sector $\mathrm{j}$ at time t. It is measured by using the sum of squares of firm's value of revenue share out of the industry level revenue. The entry of foreign firms in the market may decrease the industry concentration and enhance competitiveness and forcing domestic firms to improve productivity. This measure, therefore, captures the effect of sector level concentration on productivity of firms.

$\mathrm{HHI}$ for both domestic and foreign firms is computed by using the following formula

$$
\mathrm{HHI}=\sum_{i=1}^{n}\left(\frac{T R_{i j t}}{T R_{j t}}\right)^{2}
$$

$\mathrm{TR}_{\mathrm{ij}}$ is the total revenue of firm $\mathrm{i}$ industry $\mathrm{j}$ at time $t$

$\mathrm{TR}_{\mathrm{j}}$ is the total revenue of industry $\mathrm{j}$ at time $t$.

Capital Intensity(Capijt): represents measure of capital intensity of firm $i$ in industry $j$ at time t. Capital in this model is represented by real net tangible capital at the end of the year which shows the value of fixed assets at the end of the year. Therefore, capital intensity is measured by ratio of value of fixed assets to total number of employees.

Age ijt $_{\text {: }}$ is age of the firm $i$ in industry $j$ at time t. Age of the firm is calculated by deducting year of commencement from the year when the survey is conducted.

\subsection{Estimation Results and Discussion}

In this section, all the main estimation results of the model are presented. The fixed effects estimator is preferred after conducting the hausman specification test. The dependent variable is regressed over the FDI spillover variables consisting of labor mobility, other channels of horizontal spillovers, the interaction terms and other control variables. In order to capture the net spillovers effect of foreign firm presence on productivity, in our econometric analysis, we include other observable factors affecting the productivity of domestic firms. After testing their respective significance industry specific and firm specific effects are also incorporated in the model to capture unobserved factors affecting productivity. Moreover, lagged spillovers variable is also included in the 
model as the spillovers effect of foreign firm presence on the productivity of domestic firms may take time to manifest.

The fixed effects estimation results for the baseline model containing only the horizontal spillovers variables and the interaction terms as an explanatory variable (Model 1) and the model incorporating observable control variables in addition to variables incorporated in the baseline model (Model 2) is presented below. In estimating both models, robust option is used to control the problem of hetrosedasticity.

Table 2: Fixed Effects Estimation for Model 1 and Model 2

Dependent Variable- labor productivity (2003-2010)

\begin{tabular}{|c|c|c|}
\hline & $\begin{array}{l}\text { Model } 1 \\
\text { (Baseline Model) }\end{array}$ & $\begin{array}{c}\text { Model } 2 \\
\text { (Model with control variables) }\end{array}$ \\
\hline \multirow[t]{2}{*}{$\left(F D I_{j t}\right)$} & $4.881^{* * *}$ & $3.501^{* * *}$ \\
\hline & $(0.7910)$ & $(0.7291)$ \\
\hline \multirow[t]{2}{*}{ (FDIEjt) } & -0.001 & -0.002 \\
\hline & $(0.0024)$ & $(0.0024)$ \\
\hline \multirow[t]{2}{*}{$\left(\right.$ FDIE $\left._{\mathrm{jt}}{ }^{*} 1 \mathrm{~b}_{\mathrm{ct}}\right)$} & $-1.428 * * *$ & $-1.006^{* *}$ \\
\hline & $(0.2270)$ & $(0.2088)$ \\
\hline \multirow[t]{2}{*}{$\left(\mathrm{FDI}_{\mathrm{jt}}{ }^{*}\right.$ fin $\left._{\mathrm{ct}}\right)$} & 0.011 & $0.060^{* *}$ \\
\hline & $(0.3492)$ & $(0.0175)$ \\
\hline \multirow[t]{2}{*}{$\left(\mathrm{FDI}_{\mathrm{jt}}{ }^{*} \mathrm{Open}_{\mathrm{ct}}\right)$} & $1.913^{* * *}$ & 0.012 \\
\hline & $(0.3827)$ & $(0.0373)$ \\
\hline \multirow[t]{2}{*}{ (FDIjt $\left.{ }^{*}{ }^{\prime} u_{\mathrm{ct}}\right)$} & $0.105^{* * *}$ & $0.115^{* * *}$ \\
\hline & $(0.0247)$ & $(0.2471)$ \\
\hline \multirow[t]{2}{*}{$\left(\mathrm{FDI}_{\mathrm{jt}}{ }^{*}\right.$ inv $\left._{\mathrm{ct}}\right)$} & $-0.033^{* * *}$ & 0.032 \\
\hline & $(0.0066)$ & $(0.0067)$ \\
\hline \multirow[t]{2}{*}{$\left(\mathrm{HHI}_{\mathrm{ijt}}\right)$} & & 0.001 \\
\hline & & $(0.0009)$ \\
\hline \multirow[t]{2}{*}{ (Capijt) } & & $0.193 * * *$ \\
\hline & & $(0.0148)$ \\
\hline \multirow[t]{2}{*}{$\left(\right.$ Age $\left._{\mathrm{ijt}}\right)$} & & $0.258^{* * *}$ \\
\hline & & $(0.0729)$ \\
\hline \multirow[t]{2}{*}{$\left(\right.$ Size $\left._{\mathrm{ijt}}\right)$} & & $-0.356^{* * *}$ \\
\hline & & $(0.0442)$ \\
\hline \multirow[t]{2}{*}{ Constant } & $6.113^{* * *}$ & $5.3218 * * *$ \\
\hline & $(1.317)$ & $(0.263)$ \\
\hline Observations & 9324 & 8994 \\
\hline$R$-Squared & 0.04 & 0.16 \\
\hline
\end{tabular}

As shown in table 2 above, the two columns present the regression results of the baseline model (Model 1) and the model with additional control variables (Model 2). The joint significance test result for control variables shows that the variables are significant (Annex 8). Moreover, the goodness of fit result also shows that the explaining power of the explanatory variables is better in the model containing observable control variables than the baseline model. The magnitude of the coefficients and standard errors are lower in the model with control variables implying that the biasness of estimators is lower in the extended model relative to the baseline model. To test the robustness of the results, we alternatively remove control variables to check whether the sign or significance of horizontal spillover variables change in the absence of some control variables the result remains the same as the horizontal spillover variables are very robust.

In order to isolate the net effect of productivity spillovers, the model incorporating firm specific and industry specific effects is estimated after checking their respective significance The significant test result indicates that unobservable factors such as location and attractiveness of a particular firm or industry affects productivity. Therefore, we control this effect by incorporating firm specific and industry specific fixed effects (Annex 10).

Table 3 below presents the fixed effects estimation result of the model with interaction and observable control variables (Model 2) and the model incorporating industry and firm specific fixed effects in addition to the 
interaction and control variables (Model 3). The estimation result of Model 3 is more reliable as it shows the net FDI spillover effect on productivity after controlling both observed and unobserved factors affecting domestic firms' productivity.

Table 3: Fixed Effects Estimation for Model 2 and Model 3 Dependent Variable- Labor Productivity

\begin{tabular}{|c|c|c|}
\hline & $\begin{array}{l}\text { Model } 2 \\
\text { (with control variables) }\end{array}$ & $\begin{array}{c}\text { Model 3 } \\
\text { (with entity fixed effects) }\end{array}$ \\
\hline \multirow[t]{2}{*}{$\left(F D I_{j t}\right)$} & $3.501^{* * *}$ & $5.364^{* * *}$ \\
\hline & $(0.7291)$ & $(0.7247)$ \\
\hline \multirow[t]{2}{*}{ (FDIEjt) } & -0.002 & $-0.0054^{*}$ \\
\hline & $(0.0024)$ & $(0.0024)$ \\
\hline \multirow[t]{2}{*}{ (FDIE $\left.{ }_{j t}^{*} l a b_{c t}\right)$} & $-1.006^{* *}$ & $-1.539 * * *$ \\
\hline & $(0.2088)$ & $(0.2057)$ \\
\hline \multirow[t]{2}{*}{$\left(\mathrm{FDII}_{\mathrm{jt}}{ }^{*} \mathrm{fin}_{\mathrm{ct}}\right)$} & $0.060^{* *}$ & $0.047^{*}$ \\
\hline & $(0.0175)$ & $(0.2108)$ \\
\hline \multirow[t]{2}{*}{$\left(\right.$ FDI $_{\mathrm{jt}}{ }^{*}$ open $\left._{\mathrm{ct}}\right)$} & 0.012 & $0.1048^{*}$ \\
\hline & $(0.0373)$ & $(0.4261)$ \\
\hline \multirow[t]{2}{*}{$\left(\right.$ FDI $_{\mathrm{jt}}{ }^{*}$ hum $\left._{\mathrm{ct}}\right)$} & $0.115^{* * *}$ & $0.1129 * * *$ \\
\hline & $(0.2471)$ & $(0.0252)$ \\
\hline \multirow[t]{2}{*}{$\left(\mathrm{FDI}_{\mathrm{jt}}{ }^{*} \mathrm{inv}_{\mathrm{ct}}\right)$} & 0.032 & 0.009 \\
\hline & $(0.0067)$ & $(0.057)$ \\
\hline \multirow[t]{2}{*}{$\left(\mathrm{HHI}_{\mathrm{ijt}}\right)$} & 0.001 & 0.004 \\
\hline & $(0.0009)$ & $(0.0114)$ \\
\hline \multirow[t]{2}{*}{$\left(\mathrm{Cap}_{\mathrm{ijt}}\right)$} & $0.193^{* * *}$ & $0.247^{* * *}$ \\
\hline & $(0.0148)$ & $(0.0964)$ \\
\hline \multirow[t]{2}{*}{ (Age $\left.\mathrm{Aijt}_{\mathrm{it}}\right)$} & $0.258 * * *$ & $0.254^{* * *}$ \\
\hline & $(0.0729)$ & $(0.0354)$ \\
\hline \multirow[t]{2}{*}{$\left(\right.$ Size $\left._{\mathrm{ijt}}\right)$} & $-0.356^{* * *}$ & $-0.0367^{*}$ \\
\hline & $(0.0442)$ & $(0.0178)$ \\
\hline \multirow[t]{2}{*}{ Constant } & $5.3218^{* * *}$ & $5.0945^{* * * *}$ \\
\hline & $(0.263)$ & $(0.796)$ \\
\hline Observations & 8994 & 8994 \\
\hline$R$-Squared & 0.16 & 0.48 \\
\hline Industry Fixed Effects & No & Yes \\
\hline Firm fixed effects & No & Yes \\
\hline
\end{tabular}

As we can see from the above estimation result (table 3), apart from the observable control variables the inclusion of the unobservable firm and industry fixed effects in Model 3 increases the goodness of fit of the model. We did not find a difference in sign of the coefficients in the two models. However, the labor mobility effect of foreign firm presence (FDIE) becomes significant after we control for unobserved firm and industry level heterogeneity. Similarly, the interaction of horizontal spillovers variable with degree of openness becomes significant when we incorporate firm and industry fixed effects in our estimation. Moreover, in both models, the effect of the interaction of spillovers variable with investment freedom index of the country (FDI*inv) and sectoral concentration index (HHI) on productivity remains not significant but positive.

As we can see from the result in the above table 3, both estimates produce a positive and significant coefficient for horizontal spillovers variable other than the labor mobility channel (FDI). The result reiterates that productivity effect of technological transfer through channels other than labor mobility is not only positive but also relatively large in magnitude which is almost similar with the firm level study finding by Farole and Winkler (2013). This might be the result of technology diffusion from foreign firms to domestic firms arising from proximity and interaction; as most manufacturing firms in Ethiopia are located in similar industrial zone with the foreign industries. Therefore, exposition to marketing strategies, production process and distribution networks of multinationals enhances the productivity of domestic firms. The result is consistent with the previous finding by 
Ermias (2013).

According to (Javorcik,2004b) the spillovers through imitation will be more effective when firms produce similar products .This is also true for the case of manufacturing industry in Ethiopia as the Chinese, Indian and Turkey companies, which produces closely substitute products with the Ethiopian firms, dominates the industry. Moreover, the positive spillovers effect might be attributed to the lower technological gap between domestic and foreign firms The finding by (Amighini and Sanfilippo,2014) revealed that technological spillovers from SouthSouth FDI is potentially positive as smaller technological gap increases the chance to absorb spillovers by the local firms.

Most of the empirical studies do not isolate the labor mobility and other channels of horizontal transfer, arguing that what matters is the net effect (Jude, 2013). However, by analyzing only the net effect of FDI spillovers we do not know whether horizontal knowledge spillovers through labor mobility channel is positive or negative.The labour mobility effect of FDI spillovers might be either negative or positive depending on the capacity of domestic firms to attract workers working in multinationals (Farole and Winkler,2012). The estimation result (Model 3) shows that horizontal spillover through the labor mobility channel negatively affects productivity of domestic firms and it is also significant. The result is contrary to empirical study by Jude (2013) and Merlevede (2007) on Romanian firms and Balsvik (2011) on Norwegian manufacturing firms.

According to Farole et al (2014) and Hoekman and Javorcik (2006) the short-run labor mobility effect will be reversed in the medium term as skill and knowledge of workers may not be completely internalized by multinationals. Accordingly, we re-estimate the model by incorporating the lagged value of the spillovers variable through labor mobility (LFDIE)) in the model. The result is remaining negative but insignificant (Annex 12). Therefore, the short-run labor mobility from domestic to foreign firms with in the manufacturing industry will not be reversed at least in one year. This is attributed to high wage and benefit package gap between domestic and foreign firms in the country which results in labor turnover to foreign firms and forces domestic firms either to pay higher wage or hire less productive workers. According to (Lipsey et al., 2004) spillovers through labor mobility to domestic firms is lower in low income countries as there is high wage differential between multinationals and domestic firms.

As far as the role of the mediating factors is concerned, the result is in line with our priori expectation. Labor market regulation affects the frequency and nature of transmission of FDI spillovers in to domestic firms. As we can see from the result in table 3 above, the interaction of labor mobility channel of horizontal transfer with labor freedom index $\left(F D I E^{*} l a b\right)$ results in a significantly negative effect on productivity of domestic firms. This might be the outcome of highly flexible labor market regulation in the country. According to Farole and Winkler (2012) and Hale and Long (2011) highly flexible labor market results in frequent turnovers which reduces chance for acquiring spillovers from multinationals.

In contrast, the other mediating factors interact positively with the horizontal spillovers variable. According to Hermes and Lensink (2003) as cited in Crespo and Fontoura (2007) financial sector efficiency and development positively mediates FDI spillovers as it enhances the capacity to imitate technologies and upgrade employees qualification. As shown in the above table, Model 3, the interaction of FDI spillovers variable with financial freedom and development $\left(F D I^{*} f i n\right)$ ) shows a positive and statistically significant effect on the productivity of domestic firms. In relation to the program of transforming the country in to "manufacturing power house"; credit priority is given to domestic investors' engaged in labor intensive manufacturing industries in Ethiopia. Moreover, the expansion of banking industry in Ethiopia improves credit availability for domestic firms. This facilitates the domestic firms' absorptive capacity and reduces the risk of investment to imitate technology as well as enhances spending on workers job training. The finding is in line with the firm level study result by Farole and Winkler (2012) and Agarwal et al (2011).

The extent of FDI spillovers also depends on the nature of trade policy regime. As we can see from the estimation result, Model 3, the degree of openness interacts positively with spillovers variable (FDI*open) and significantly affects the productivity of domestic manufacturing firms in Ethiopia. This is attributed to presence of export-oriented foreign firms in the manufacturing sector after the government adopts export promotion policy. This creates an opportunity for domestic firms to interact with foreign firms and learn through exporting.

The firm level study by Li et al (2001) confirms that the efficiency of local Chinese firms increases due to the presence of export-oriented FDI firms in the country. The result is also in line with the firm level study by Farole and Winkler (2012) on firms in low and middle-income countries and Temenggung (2007) on Indonesian manufacturing firms. Moreover, (Crespo and Fontoura, 2011) reiterated that FDI spillovers are likely to be positive in countries adopting open trade policies and export promotion strategy than import substitution strategy which supports our finding.

According to Jude (2013) horizontal spillovers mainly depends on human capital relative to the vertical transfers. As we can see from the above table, the interaction of human capital with the FDI spillovers variable $\left(F D I^{* h u m}\right)$ ) results in a positive and significant effect on productivity of domestic firms. This is attributed to the rising share of government expenditure on education combined with increasing number of people with completed 
secondary and tertiary education which, in turn, increases the share of skilled labor in the industry. The presence of better human capital enhances the domestic firms' absorptive capacity and facilitates the intra-industry technology and knowledge transfer in the country.

According to Boly et al (2013) and Farole et al (2014) the demonstration effect on domestic firms highly depends on availability of learning and innovation infrastructure. The finding is also similar with the previous firm level study by Farole and Winkler (2012) and finding by Blalock and Gertler (2009) on Indonesian manufacturing sector.

As far as the control variables are concerned, the sign of the coefficients is in line with our priori expectation except in the case of firm's size. The significance of the control variables is also consistent both in Model 2 and Model 3. The unexpected sign of the size variable might be attributed to the inverse relationship between firm size, measured in total number of employees, and labor productivity, measured using value added per worker. Moreover, age of the firms positively and significantly affects firms' productivity. The longer the firm stays in the industry, the higher will be the chance to have better absorptive capacity and reap positive spillovers which enhances productivity. The finding is in line with firm level study by (Sanfilippo and Seric, 2014).

\section{Conclusions}

This paper is aimed at analyzing the role of host country characteristics and institutional framework on FDI spillovers in Ethiopia focusing on the manufacturing firms. As far as our knowledge is concerned, this is the first study to analyze the effect of interaction of FDI with mediating factors on productivity of firms in Ethiopia. In this study, we also try to separate the labor mobility channel from the other channels of horizontal spillovers. Moreover, to be more confident about the net spillovers effect of the presence of foreign firms with in the manufacturing industry other observable and unobservable factors affecting productivity of domestic firms were incorporated.

Panel data econometric analysis with fixed effects estimation technique is used. Accordingly, we estimate the baseline model, the model with control variables and the model incorporating firm and industry specific effects to assess the net spillovers effects of FDI. The estimation result reiterates that the presence of foreign firms positively affects the productivity of domestic firms in horizontal channels other than labor mobility channel. However, the presence of foreign firms results in employee's turnover from domestic to foreign firms which adversely affect the productivity of domestic firms. The labor turnover effect will not reverse even in one year .The empirical estimation result of the interaction term also shows that the labor mobility from domestic to foreign firms might also be attributed to the loose labor market regulation of the country.

On the other hand, the estimation result reiterated that the country's financial sector improvement in terms of banking efficiency and growing human capital stock positively mediates the spillovers effect from FDI. Moreover, export-oriented trade policy of the country enhances the productivity of domestic firms as it facilitates learning through exporting. Similarly, the investment freedom positively moderates the spillovers effect of FDI although it is not significant. The effect of sectoral concentration on productivity of firms is also positive but insignificant.

As far as the control variables are concerned, the capital intensity and age of the domestic firms positively and significantly affects the productivity of domestic firms. We find unexpected sign for the variable firm size which might be attributed to the inverse relationship between our productivity and size measures in our model.

\section{References}

Abeba, T.(2014) "FDI and the Spillovers Effect Analaysis: The Case of Ethiopia”, IES Working Paper, Charles University in Prague, Institute of Economic Studies.

Abraham,F.,Konings, J. andSlootmaekers,V.(2010) "FDI Spillovers in Chinese Manufactring Sector: Evidence of Firm Hetrogeniety" Economies of Transition No. 18, PP. 143-82.

Agarwal,N. Milner,C. and Riano,A.(2011) "Credit Constraints and FDI Spillovers in China", China and World Economy Research Series No.21/2011, University of Nottingham.

Alfaro,L., Chanda ,A., Kalemli-Ozcan,S. and Sayek,S.(2004) "FDI and Economic Growth: The Role of Local Financial Markets", Journal of International Economics, 64, 89-112.

Amendolagine,V., Boly,A., Coniglio,N. and Prota,F.(2013) "FDI and Local Linkags in Developing Countries: Evidence from Sub-Saharan Afrcia”, Development Policy, Statistics and Research Branch Working Paper No7.2012, UNIDO, Austria, Vienna.

Amighini, A. and Sanfilippo,M.(2014) "Impact of South-South FDI and Trade on Export Up grading of African Economies, World Development, 64:1-17.

Asiedu, E.(2005) "Foreign Direct Investment in Africa: The Role of Natural Resources, Market Size, Government Policy, Institutions and Political Instability", UN-WIDER Research Paper, No.2005/24.

Balsvik, R.(2011) "Is Labor Mobility Channel for Spillovers from Multinationals? Evidence from Norweigan Manufacturing", Review of Economics and Statistics 93(1): 285-97.

Bhagwati, J.(1978). “Anatomy and Consequences of Exchange Control Regimes”, New York: Balinger Publishing. Blalock,G.and Gertler, P.J.(2009) "How Firm Capabilities Affect Who Benefiits from Foreign Technology", 
Journal of Development Economics, 90(2):192-199.

Boly,A., Coniglio,N.,Prota,F.and Seric,A.(2013) "Which Domestic Firms Benefit from FDI? Evidence from Selected African Countries", Development Policy, Statistics and Research Branch Working paper 8/2012. UNIDO, Austria ,Vienna.

Clark,P.C.(2013) "The Effects of Multicollinearity in Multilevel Models", Unpublished Doctoral Dissertation, Wright State University. Accessed https://etd.ohiolink.edu/!etd.send file?accession=wright1375956788\&disposition=inline

(last consulted : $12^{\text {th }}$ August,2015).

Costa da Massingue,C.(2012) “Are There Spillover Effects from Foreign Direct Investment in Sub-Saharan Africa? Asessing the Linkage Effects in Mozambique”, Unpublished Masters Dissertation, University of London.

Crespo,N. and Fontoura,M.(2007) “Determinants Factors of FDI Spillovers-What Do We Really Know?" World Development 35(3):410-25.

Cuervo-Cazurra,A. and Genc,M.(2008) "Transforming Disadvantages in to Advantages: Developing-Country MNEs in Least Developed Countries", Journal of International Business Studies 39(6):957-79.

Demeke, A., Dereje, T. and Han, D.G.(2012) "Determinants of Foreign Direct Investment: Reflections from Ethiopia", Social and Basic Sciences Research Review, 2(2):85-95.

Ermias, S. (2013) “The Spillovers Effects of Foreign Direct Investment Inflow on Productivity of Domestic Firms: A Case of Ethiopian Manufacturing Firms”, Unpublished Masters Dissertation, Institute of Social Studies, The Hague, Netherlands. Accessed on http://thesis.eur.nl/pub/15425/ (last consulted: 18 ${ }^{\text {th }}$ July, 2015).

Farole,T., Staritz, C.and Winkler,D.(2014) "Making Foreign Direct Investment Work for Sub-Saharan Africa: Local Spilovers and Competitivness in Global Value”, the World Bank, Washington, D.C.

Farole,T.and Winkler,D.(2012) "Foreign Firm Characterstics, Absorpitive Capacity and the Institutional Framework:The Role of Mediating Factors for FDI Spillovers in Low and Middle-Income Countries ”, Policy Research Working Paper No. 6265, World Bank, Washington, DC.

Fosfuri,A.,Motta, M. and Ronde,T.(2001)“Foreign Direct Investment and Spillovers Through Workers' Mobility",Journal of International Economics ,53(1):205-22.

Frederick,S. and Staritz,C.(2012) "Developments in the Global Apparel Industry after the MFA Phase out", in Lopez-Acevodo,G. and Robertson,R.(eds.) Sewing Success? Employment, Wages and Poverty following the End of the Multifiber Arrangement, PP.41, World Bank, Washington DC.

Girma,S.(2005) "Absorptive Capacity and Productivity Spillovers from FDI: A Threshold Regression Anaysis", Oxford Bulletin of Economics and Statistics 67(3): 281-306.

Gorg, H. and Strobl,E.(2005) " Spillovers from Foreign Firms through Workers Mobility: An Emperical Investigation”, Scandinavian Journal of Economics, 107, 693-709.

Greene, W.H.(2003) "Econometric Analysis", 5 $5^{\text {th }}$ edition. Pearson Education, Inc. Delhi, India.

Greenway, D., Sousa,N. and Wakelin,K.(2004) "Do Domestic Firms Learn to Export from Multinationals?" European Journal of Polictical Economy 20(4): 1027-43.

Hale ,G.and long,C.(2011) “Did FDI Put an Upward Pressure on Wage in China?”, IMF Economic Review, No.59: PP.404-30.

Havranek,T. and Irsova.Z.(2011) "Estimating Vertical Spillovers from FDI: Why Results Vary and What the True Effect Is", Journal of International Economics, No.85., PP.234-44.

Henok, G.(2014) "Determinants and Impediments of FDI Inflow in Ethiopia: A Firm Level Investigation ", MPRA Paper No.55955.

Hermes,N. and Lensink, R.(2003) "Foreign Direct Investment, Financial Development and Economic Growth", Journal of Development Studies, 40(1), 142-163.

Hoekman,B. and Javorcik,B.(2006) "Lessons from Emperical Research on Technology Diffusion Through Trade and Foreign Direct Investment”, In Global Integration and Technology Transfer, World Bank, Washington, DC.

Javorcik,B.(2004) "Does Foreign Direct Investment Increase the Productivity of Domestic Firms? In Search of Spillovers through Backward Linkages", American Economic Review 94(3): 605-27.

Javorcik, B.(2004b)“The Composition of Foreign Direct Investment and Protection of Intellectual Property Rights: Evidence from Transition Economies”, European Economic Review 48(1):39-62.

Javorcik,B.(2008) “Can Survey Evidence Shed Light on Spillovers from Foreign Direct Investment ?” World Bank Research Observer, 23(2):139-59.

Jordaan, J.(2011) "Local Sourcing and Technology Spillovers to Mexican Suppliers: How Important Are FDI and Supplier Characterstics?" Growth and Change 42(3): 287-319.

Kohpaiboon,A.(2009) "Vertical and Horizontal FDI Technology Spillovers: Evidence from Thai Manufacturing", in Corbett,J.and S.Umezaki (eds.) Deepening East Asian Economic Integration. ERIA Research Project Report 2008-1,PP.314-355.Jakarta:ERIA.

Kokko,A., Zejan,M. and Tansini,R.(2001) “Trade Regimes and Spillover Effects of FDI: Evidence from Uruguay”, 
Weltwirtschaftliches Archiv,137(1), 124-149.

Lesher,M. and Miroudot,S.(2008) "FDI Spillovers and Their Interrelationships with Trade", OECD Trade Policy Working Paper No.80, Organization for Economic Co-opration and Development(OECD), Paris.

Li,X., Liu,X. and Parker,D.(2001) "Foreign Direct Investment and Productivity Spillovers in the Chinese Manufacturing Sector”, Economic Systems 25(4): 305-21.

Lipsey,R. and Sjoholm,F.(2004) "Foreign Direct Investment, Education and Wages in Indonesian Manufacturing”, Journal of Development Economics ,73, 415-422.

Lipsey,R. and Sjoholm,F.(2005) “The Impact of Inward FDI on Host Countries:Why Such Different Answers?", in Moran,T.,E. Graham, and M.Blomstrom(eds.) Does Foreign Direct Investment Promote Development?, pp.23-43, Washington,D.C.: Institute for International Economics and Center for Global Development.

Melaku,T.A.(2013) “Total Factor Productivity and Technical Effeciency in the Ethiopia Manufacturing sector", EDRI Working Paper No.10, Addis Ababa, Ethiopia.

Merlevede,B. and Schoors,K.(2007) "FDI and the Consequences: Towards More Complete Capture of Spillover Effects," William Davidson Institute Working Papers Series No. 886, William Davidson Institute at University of Michigan.

MOFED(2014) “Growth and Transformation Plan Annual Progress Report for 2012/13”, Addis Ababa, Ethiopia.

Nicolini,M.and Resmini,L.(2010) "FDI Spillovers in New EU Member States," Economics of Transition, 18(3): 487-511.

Ofosu,A. and Waldkirch,A.(2008) "Foreign Presence,Spillovers and Productivity: Evidence from Ghana", MPRA Paper No.8577.

Perez-Vilar,L. and Seric,A.(2014) "Multinationals in Sub-Saharan Africa: Domestic Linkages and Institutional Distance", Kiel Working Papers No.1893, Kiel Institute for the World Economy, Germany.

Rao,K.R. and Tesfahunegn,S.Z.(2015)“Performance Measurement of Manufacturing Industries in Ethiopia-An Analytical Study", Journal of Poverty, Investment and Development Vol.7, No.2422.

Sanfilippo,M. and Seric,A.(2014) "Spillovers form Agglomerations and Inward FDI: A Multilevel Analysis on Sub-Saharan African Firms", Europenan University Institute and United Nations Industrial Organizations.

Sheferaw and Tadele (2015) "Economic Growth and Employment Patterns, Dominant Sector, and Firm Profiles in Ethiopia: Opportunities, Challenges and Prospects", R4D Working paper 2015/2, Swiss Programme for Research on Global Issues for Development.

Smeets,R.(2011) “Collecting the Pieces of the FDI Knowledge Spillovers Puzzle”, World Bank Research observer, 23(2):107-38.

Stancik,J (2009) “FDI Spillovers in the Czech Republic: Takeovers Vs.Greenfields”, Economic papers, No.369, European Economic Commission.

Temenggung,D.(2007) "Productivity Spillovers from Foreign Direct Investment:Indonesian Manufacturing Industry’s Experience 1975-2000”, Australian National University, Canberra, Australia.

Torres-Reyna, O.(2008) "Panel Data Analysis: Fixed and Random Effects", Princeton University Accessed on http://www.princeton.edu/ otorres/Panel101.pd (last consulted, $25^{\text {th }}$ July,2015).

Tytell, I. and Yudaeva, K.(2007) "The Role of FDI in Eastern Europe and New Independent States: New Channels for the Spillover Effect", in Liebscher,K.,J.Christl,P. Mooslechner, and D.Ritzberger-Grunwald (eds.) Foreign Direct Investment in Europe: A changing landscape, PP.76-78. ,Cheltenham, U.K. Edward Elgar.

Zhou,Y.(2014) "FDI and Technical Effeciency in Manufacturing Firms: A Stochastic Frontier Approach", Master's Thesis, Department of Economics, University of San Francisco. 


\section{Appendices}

Annex 1: Descriptive Statistics

\begin{tabular}{r|rrrrr} 
Variable & Obs & Mean & Std. Dev. & Min & Max \\
\hline prod & 9324 & 6.171275 & 1.80773 & -6.956945 & 14.7034 \\
fdi & 11131 & 7.387945 & 13.97859 & 0 & 100 \\
fdie & 11131 & 4.523036 & 8.460154 & 0 & 100 \\
fdielab & 11131 & 30.39616 & 57.56092 & 0 & 412.552 \\
fdifin & 11131 & 22.75338 & 42.77702 & 0 & 340.12 \\
\hline \multirow{2}{*}{ fdiopen } & 11131 & 28.05519 & 53.20669 & 0 & 391.606 \\
fdihum & 11131 & 24.95592 & 47.86053 & 0 & 351.328 \\
fdiinv & 11131 & 26.61467 & 51.26455 & 0 & 391.202 \\
hhi & 11131 & 18.31375 & 18.93557 & 0 & 100 \\
cap & 10981 & 6.455683 & 2.728485 & 0 & 17.88982 \\
\hline \multirow{2}{*}{ age } & 11013 & 2.840082 & .5594458 & 0 & 4.65396 \\
size & 10976 & 3.220183 & 1.256391 & 0 & 8.976389
\end{tabular}

Note: prod, cap, age and size variables are taken in their log transformed form after Conducting normal distribution test

\section{Annex 2: Hausman Specification Test}

\begin{tabular}{r|cccc}
\cline { 2 - 4 } & $(\mathrm{b})$ & $(\mathrm{B})$ & $(\mathrm{b}-\mathrm{B})$ & \\
& $\mathrm{fe}$ & $\mathrm{re}$ & Difference & $\begin{array}{c}\text { sqrt }\left(\text { diag }\left(V_{-} b-V_{-} B\right)\right) \\
\text { S.E. }\end{array}$ \\
\hline fdi & -2324.233 & -1786.545 & -537.6881 & 743.953 \\
fdie & 63.96574 & 29.01327 & 34.95247 & 83.29886 \\
fdielab & -2.144766 & -.1439465 & -2.000819 & 1.367313 \\
fdifin & -1452.675 & -1067.428 & -385.247 & 163.4962 \\
fdiopen & 3343.439 & 2418.179 & 925.2606 & 202.07 \\
fdihum & -1238.137 & -778.7148 & -459.4224 & 163.3857 \\
fdiinv & -440.5409 & -385.6498 & -54.89108 & 38.17762 \\
hhi & 36.35419 & 66.6037 & -30.24951 & 8.187162 \\
cap & .000278 & .0005877 & -.0003097 & .0001601 \\
age & -102.9602 & -105.6332 & 2.673044 & 23.09402 \\
size & -7.00735 & -5.272279 & -1.73507 & 1.194738 \\
\hline
\end{tabular}

$\mathrm{b}=$ consistent under $\mathrm{Ho}$ and $\mathrm{Ha}$; obtained from xtreg

$\mathrm{B}=$ inconsistent under $\mathrm{Ha}$, efficient under $\mathrm{Ho}$; obtained from xtreg

Test: Ho: difference in coeficients not systematic

$$
\begin{aligned}
\operatorname{chi2}(10) & =(b-B){ }^{\prime}\left[\left(V_{-} b-V_{-} B\right)^{\wedge}(-1)\right](b-B) \\
& =55.38 \\
\text { Prob }>\text { chi2 } & =0.0000
\end{aligned}
$$




\section{Annex 3: Test for Hetroskedasticity}

- xttest3

Modified Wald test for groupwise heteroskedasticity

in fixed effect regression model

HO: $\operatorname{sigma}(i)^{\wedge} 2=\operatorname{sigma}^{\wedge} 2$ for all $i$

$\operatorname{chi2}(4459)=4.6 e+40$

Prob $>$ chi2 $=0.0000$

\section{Annex 4: Test for Autocorrelation}

- xtserial prod fdi fdie fdielab fdifin fdiopen fdihum fdiinv hhi cap age size

Wooldridge test for autocorrelation in panel data

HO: no first order autocorrelation

$$
\begin{aligned}
\mathrm{F}(1,1086) & =0.696 \\
\text { Prob }>\mathrm{F} & =0.4043
\end{aligned}
$$

\section{Annex 5: Test for Endogeniety: Correlation Matrix}

\begin{tabular}{r|r} 
& residual \\
\hline residual & 1.0000 \\
prod & 0.0749 \\
fdi & 0.1615 \\
fdie & 0.0354 \\
fdielab & 0.0427 \\
fdifin & 0.1514 \\
fdiopen & 0.1707 \\
fdihum & 0.1732 \\
fdiinv & 0.1045 \\
hhi & 0.3146 \\
cap & 0.2684 \\
age & -0.4320 \\
size & -0.4340
\end{tabular}




\section{Annex 6: Test for collinearity}

corr prod fdi fdie lab fin open hum inv gdp bus hhi cap age size (obs $=11011$ )

\begin{tabular}{|c|c|c|c|c|c|c|c|c|c|c|c|c|c|c|}
\hline & prod & fdi & fdie & lab & fin & open & hum & inv & gdp & bus & hhi & cap & age & size \\
\hline prod & 1.0000 & & & & & & & & & & & & & \\
\hline fdi & 0.0251 & 1.0000 & & & & & & & & & & & & \\
\hline fdie & 0.0319 & 0.2323 & 1.0000 & & & & & & & & & & & \\
\hline $1 a b$ & 0.0145 & 0.0862 & 0.0639 & 1.0000 & & & & & & & & & & \\
\hline fin & -0.0528 & -0.1120 & 0.0132 & 0.5183 & 1.0000 & & & & & & & & & \\
\hline open & -0.0024 & 0.0247 & 0.0284 & 0.2835 & -0.0316 & 1.0000 & & & & & & & & \\
\hline hum & 0.0265 & 0.0909 & 0.0376 & 0.5534 & 0.0248 & 0.5632 & 1.0000 & & & & & & & \\
\hline inv & -0.0886 & -0.1691 & -0.0430 & -0.1902 & 0.3993 & 0.4469 & 0.0472 & 1.0000 & & & & & & \\
\hline$g d p$ & 0.0710 & 0.1836 & 0.0490 & 0.2111 & -0.2883 & 0.6959 & 0.5281 & 0.0201 & 1.0000 & & & & & \\
\hline bus & 0.0944 & 0.2163 & 0.0412 & -0.0816 & -0.5818 & 0.3664 & 0.2161 & -0.2723 & 0.8830 & 1.0000 & & & & \\
\hline hhi & 0.0427 & 0.0227 & 0.0518 & -0.0910 & -0.0635 & -0.1851 & -0.1347 & -0.1401 & -0.1145 & -0.0211 & 1.0000 & & & \\
\hline cap & 0.0364 & 0.0357 & 0.0395 & 0.0372 & -0.0692 & -0.0118 & 0.0420 & -0.1427 & 0.1011 & 0.1352 & 0.0469 & 1.0000 & & \\
\hline age & -0.0241 & 0.0425 & 0.0612 & -0.0348 & 0.0177 & -0.0794 & -0.0660 & -0.0278 & -0.1057 & -0.0828 & 0.0417 & -0.0342 & 1.0000 & \\
\hline size & -0.0105 & 0.0193 & 0.0956 & -0.0414 & 0.0374 & -0.0188 & -0.0419 & 0.0638 & -0.0921 & -0.1006 & 0.0333 & -0.0212 & 0.2952 & 1.0000 \\
\hline
\end{tabular}

Annex 7: Estimation results of baseline model and the model incorporating control variables

\begin{tabular}{r|cc}
\hline Variable & model1 & \multicolumn{1}{c}{ Model2 } \\
\hline fdi & $4.8836441 * * *$ & $3.5016887 * * *$ \\
fdie & -.00173489 & -.00222645 \\
fdielab & $-1.4285433 * * *$ & $-1.0062534 * * *$ \\
fdifin & .01140829 & $.06027988 * * *$ \\
fdiopen & $.19133369 * * *$ & .01236974 \\
fdihum & $.10521855 * * *$ & $.11528255 * * *$ \\
fdiinv & $-.03336784 * * *$ & .00323317 \\
hhi & & .00126004 \\
cap & & $.19266421 * * *$ \\
age & & $.25833521 * * *$ \\
size & & $-.35612825 * * *$ \\
cons & $6.113139 * * *$ & $5.321836 * * *$ \\
\hline N & 9324 & 8994 \\
$r 2$ & .04263218 & .16158511 \\
r2_a & .04191282 & .16055832 \\
\hline & & \\
\hline
\end{tabular}

legend: * $p<0.05 ; * * p<0.01 ; * * * p<0.001$

\section{Annex 8: Test for joint Significance}

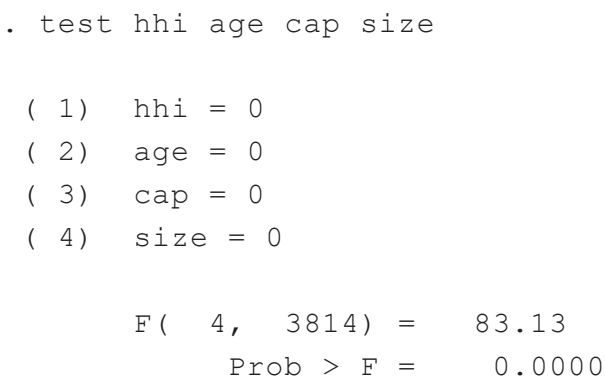




\section{Annex 10: Testing the significance of industry and firm fixed effects}

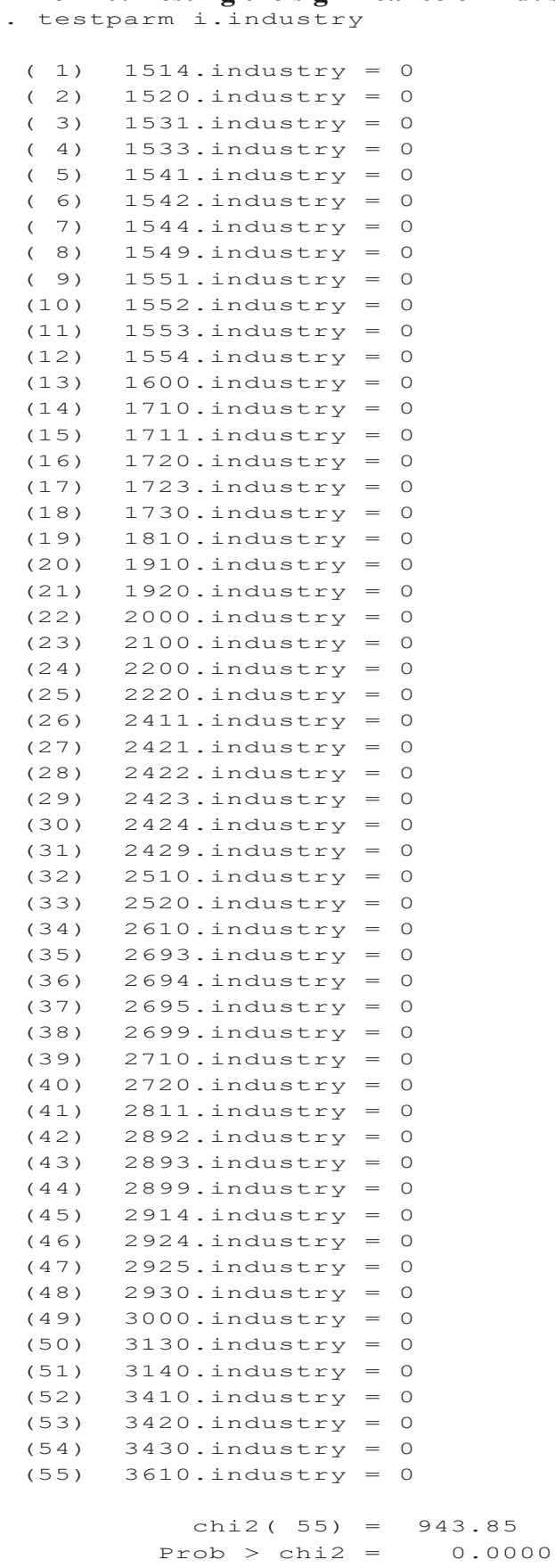

Note: We capture the firm fixed effects by incorporating absorb (firm) option in our model estimation as it is it is too large to display the test result for 11131 observations in STATA. The significance of the firm fixed effects is checked by estimating the model with and without including the absorb (firm) option. According to Torres-Reyan 2010) using either of the following two commands will give us the same result:

- areg prod fdi fdie fdielab fdifin fdiopen fdihum fdiinv hhi cap age size i.industry, absorb (firm)

OR

- xi: regress prod fdi fdie fdielab fdifin fdiopen fdihum fdiin hhi cap age size i.industry i, firm 


\section{Annex 11: Estimation results with and without incorporating industry and firm fixed effects}

- xtreg prod fdi fdie fdilab fdifin fdiopen fdihum fdiinv hhi age cap size, fe robust - areg prod fdi fdie fdilab fdifin fdiopen fdihum fdiinv hhi age cap size i.industry, absorb(firm) robust

\begin{tabular}{r|cc}
\hline Variable & model2 & model3 \\
\hline fdi & $3.5016887 * *$ & $5.3646978 * * *$ \\
fdie & -.00222645 & $-.00547532 *$ \\
fdielab & $-1.0062534 * *$ & $-1.5392134 * * *$ \\
fdifin & $.06027988 * *$ & $.04750662 *$ \\
fdiopen & .01236974 & $.1048222 *$ \\
fdihum & $.11528255 * *$ & $.1127907 * * *$ \\
fdinv & .00323317 & .00913568 \\
hhi & .00126004 & .00043857 \\
cap & $.19266421 * * *$ & $.24787347 * * *$ \\
age & $.25833521 * * *$ & $.25423924 * * *$ \\
size & $-.35612825 * * *$ & $-.03676492 *$ \\
cons & $5.321836 * * *$ & $5.0954851 * *$ \\
\hline $\mathrm{N}$ & 8994 & 8994 \\
r2 & .16158511 & .47943147 \\
r2_a & .16055832 & .33840124 \\
\hline
\end{tabular}

legend: $* \mathrm{p}<0.05 ; * \star \mathrm{p}<0.01 ; * \star * \mathrm{p}<0.001$

Annex 12: The estimation result after incorporating the lagged value of the horizontal Spillovers variable through labor mobility (Ifdie)

- areg prod fdi fdie lfdie fdielab fdifin fdiopen fdihum fdiinv hhi cap age size i.industry, absorb(firm) robust note: 1712.industry omitted because of collinearity

\begin{tabular}{|c|c|c|c|c|c|c|}
\hline \multirow[b]{2}{*}{ prod } & \multicolumn{3}{|c|}{ Robust } & \multirow[b]{2}{*}{$P>|t|$} & \multirow[b]{2}{*}{ [95\% Conf. } & \multirow[b]{2}{*}{ Interval] } \\
\hline & Coef. & Std. Err. & t & & & \\
\hline fdi & 3.647356 & .7988282 & 4.57 & 0.000 & 2.081101 & 5.213611 \\
\hline fdie & -.0073655 & .0033796 & -2.18 & 0.029 & -.0139919 & -.0007391 \\
\hline lfdie & -.0034899 & .0030151 & -1.16 & 0.247 & -.0094015 & .0024217 \\
\hline fdielab & -1.150349 & .2306233 & -4.99 & 0.000 & -1.60253 & -.6981685 \\
\hline fdifin & .0715447 & .026424 & 2.71 & 0.007 & .0197354 & .1233539 \\
\hline fdiopen & .0726828 & .0536253 & 1.36 & 0.175 & -.0324598 & .1778254 \\
\hline fdihum & .1694215 & .0387378 & 4.37 & 0.000 & .0934686 & .2453745 \\
\hline fdiinv & .0019348 & .0086579 & 0.22 & 0.823 & -.0150406 & .0189101 \\
\hline hhi & .0048962 & .0018297 & 2.68 & 0.007 & .0013087 & .0084837 \\
\hline cap & .2614863 & .0134084 & 19.50 & 0.000 & .2351966 & .287776 \\
\hline age & .1286703 & .052087 & 2.47 & 0.014 & .0265438 & .2307968 \\
\hline size & .0099198 & .0249509 & 0.40 & 0.691 & -.0390012 & .0588408 \\
\hline
\end{tabular}

